Journal of Teacher Education for Sustainability,

vol. 14, no. 2, pp. 130-146, 2012

\title{
TEACHER EDUCATION FOR SUSTAINABILITY IN NETWORK SOCIETY: COMBINING DIGITAL AND SUSTAINABILITY LITERACIES
}

\author{
John Huckle \\ University of York, the United Kingdom
}

\begin{abstract}
How should teacher education for sustainability (TEfS) respond to new information and communication technologies that can enable new forms of social and environmental relations and new forms of pedagogy? To answer that question, this article will consider the potential of Web 2.0 technologies or social media to enrich the content and pedagogy of education for sustainable development in both university and school classrooms. It will suggest that teachers should be introduced to critical social theory that seeks to explain the role of these new technologies in the recent wave of capitalist development that precipitated economic and ecological crisis, and their potential to bring about more sustainable alternatives. Such alternatives will be based on more radical and deliberative forms of democracy and citizenship enabled by the new technologies, and TEfS should equip teachers to explore these through appropriate forms of citizenship education and model them in their classrooms via new forms of critical pedagogy. Such ideas as those of Erik Olin Wright on real utopias and Manuel Castells on network society provide such TEfS with appropriate theory, while consideration of how YouTube videos might be used to develop critical digital and sustainability literacies in the classroom, illustrates how such theory might be related to practice.
\end{abstract}

Key words: teacher education for sustainability, education for sustainable development, network society

\section{New technologies, neoliberal capitalism and unsustainable development}

All teachers who claim to educate for sustainability should have a critical grasp of the structures and processes shaping the development and underdevelopment of the societies in which they teach. Teacher education for sustainability (TEfS) should help them understand that information and communication technologies linked to the internet enabled, but did not cause, the neoliberal regime of capital accumulation that began in the late 1970s and ended with the financial crisis of $2007 / 2008$. This neo-liberal era was characterised by deregulation; privatisation; the privileging of corporate power; ultra-mobile capital; globalisation; outsourcing; imperialist militarism in Iraq and Afghanistan; growing social inequality and 
unrest and increased environmental degradation. Designed to restore the rates of return on capital and further shift power to economic and political elites, it used new technologies to speed up the circulation of capital (for instance, just in time delivery); introduce new consumer and financial products and services (personal computers, spread betting); intensify globalisation (global logistics networks); wage war (pilotless aircraft); control social unrest (video surveillance); maintain ideological control (new forms of popular entertainment and media); improve environmental management (remote sensing) and introduce new priorities to schooling (computer literacy). New technologies also provided new ways of engineering nature (biotechnology) and increasing the efficiency of resource use (waste free production) that are often represented as sustainable development.

That neo-liberalism failed to revive capital's fortunes and proved unsustainable is due to three factors: its inherent instability; the increasing cost of reproducing the conditions of production and the falling demand for capital investment and workers due to technological change. Capitalism has an inbuilt tendency to grow to a state in which it cannot sell all it produces and capital must be scrapped before a new wave of accumulation can begin. In the recent neoliberal era in the West, capital accumulated as credit and property bubbles as bankers borrowed to speculate on increasingly complex financial products and households borrowed against rising property prices to maintain consumer lifestyles rendered less accessible by falling real wages. Capital was re-invested in property and financial bubbles to maintain economic growth but eventually sub-prime mortgages and complex financial products proved impossible to sell at their inflated values and the whole debt dependent regime collapsed (De Santos et al., 2009; Harvey, 2010). In Europe, a one-size-fits-all monetary policy reinforced mounting instability. Countries on the periphery had higher costs and lower productivity than those in the core, but a common interest rate allowed them to disguise their weaknesses by borrowing on the strength of inflated asset-prices and credit ratings. In the absence of controls on capital movement, trade surpluses generated in the core were recycled into Mediterranean property speculation: a situation echoed in the global imbalances between China and the West. When property and financial bubbles burst, governments stood behind their banks, bailing them out at huge public cost. The result is a collapse in public investment, growing austerity, mounting social problems and rising unemployment, particularly amongst the young.

Europe's debt crisis is compounded by ecological debt as an accelerating treadmill of production and consumption has damaged or destroyed ecological resources and services, often in other parts of the world. Capital finds it harder and more costly to reproduce the conditions of production (fertile soil, clean air and water, waste treatment, space free from pollution and congestion, healthy and suitably educated workers), and this is a further reason why recent growth has proved unsustainable (O'Connor, 1991). Capital is now seeking to shed the costs associated with reproducing the conditions of production by requiring citizens to pay for health care and education; by lobbying for further deregulation of the environment and landuse planning and by further outsourcing production to countries with cheap resources and/ or low environmental and welfare standards (Harvey, 2011). Teachers will recognise that the 
continuing restructuring of education is part of these developments and is associated with the loss of professionalism and worsening conditions of service in many European states.

Technological change is the third factor contributing to neo-liberalism's failure to revive capital's fortunes. While capitalism currently requires $3 \%$ growth to absorb the constant supply of new capital created, there is a falling demand for capital investment and workers as less capital and labour are now needed to produce each unit of output (Shutt, 2010). As markets for some manufactured goods become saturated, consumer demand shifts to services that are less capital intensive. Web technologies deliver communication and media services at reducing cost to consumers, and conventional suppliers of music, films, newspapers and postal services find it increasingly difficult to make a profit. There is growing resistance to intellectual property rights, a growth of open-source products, such as Linux and Wikipedia, and a readiness to use services, such as eBay, to buy used rather than new goods. While some take a positive view of Web 2.0's potential for business (Tapscott \& Williams, 2008, 2010), the dot com boom and bust of 1995-2000 illustrates the uncertainty that information and communication technology (ICT) brings to financial markets and the associated threat to investor confidence. Economic instability is compounded by high levels of unemployment that increase the costs of welfare, further reduce demand and pose issues for teachers seeking to motivate older school students.

\section{Network society, the network state and networked individuals}

Castells (2008) offers teachers a new way of understanding the societies created by neo-liberal capitalism and enabled by new technologies. He maintains that we live in a world marked by globalisation: the process that constitutes a social system with the capacity to work as a single unit on a planetary scale in real or chosen time. ICT, including rapid transportation and computer networks, gives the system the technological capacity to selectively connect anyone and anything to global networks that structure the planet and through which flow people, energy, materials and information. All the world's core economic, communicative and cultural activities have become dependent on strategic nodes in these networks that include global financial markets; global production and distribution of goods and services; international trade; global networks of science and technology; global media and global interactive networks of communication.

Critical issues facing people and governments around the world, such as the need for more sustainable forms of development, are largely produced and shaped by interdependent global processes that move beyond the realm of supposedly sovereign states. The power of the state is challenged by that of transnational corporations and undermined by agents within global civil society that seek alternative forms of global governance. As politics shifts to the global arena, the nation state is the source of four distinct but interrelated political crises:

- Crisis of efficiency. Problems such as climate change or regulation of financial markets cannot be adequately managed.

- Crisis of legitimacy. Governments that are less efficient lose their legitimacy and 
support from citizens. In network society, the media become the essential space of politics and its resulting simplification to images, personalities, sound bites, scandal and spin, has deepened the crisis of legitimacy. Many see politicians as selfinterested, corrupt and irrelevant to their lives.

- Crisis of identity. As people lose faith in their political identity as citizens, they seek autonomy in forms of resistance identity and cultural identity politics.

- Crisis of equity. Neo-liberalism and globalisation increase inequality within and between countries and social groups. Welfare states are undermined in the absence of a global regulatory environment.

The increasing inability of nation states to confront and manage such issues as the need for sustainable development leads to ad-hoc forms of global governance and ultimately to a new form of state. Nation states (comprising governments, parliaments, political party system, judiciary and state bureaucracy) transform themselves by three main mechanisms:

- States associate with each other forming networks of states, for instance, the European Union, North American Free Trade Agreement (NAFTA).

- States build an increasingly dense network of international institutions and supranational organisations to deal with global issues, for instance, the United Nations, International Monetary Fund, North Atlantic Treaty Organisation, United Nations Environment Programme..

- States decentralise power and resources in an effort to increase legitimacy and/or to tap into other forms of cultural or political allegiance, for instance, the Welsh Assembly in the UK.

From this three-pronged process emerges a new form of state - the network state. As it practises global governance through ad-hoc networks, it confronts major problems arising from the contradiction between the historically constructed nature of the institutions that come into the network and the new functions and mechanisms they have to assume to perform in the network while still relating to their nation bound societies. Coordination, ideological and geopolitical problems arise because the network state finds it difficult to coordinate decisionmaking and policy across many issues and agencies at many scales; to find common language, principles and values to underpin governance in such policy areas as sustainable development and to abandon the old geopolitics based on the interests of nation states for a new culture of global cooperation. These contradictions can only be overcome if the world's geopolitical actors allow the evolution of the network state into a system of constitutionally accepted networked global governance or cosmopolitan democracy with associated forms of citizenship (Held, 1995; Ferry, 2011).

A key component of network society is the global/local media system made up of oligopolistic multimedia businesses controlling the mass media and an increasingly inclusive hypertext; a multitude of horizontal networks of autonomous local/global communication and the interactions between the two systems that form a complex pattern of connections and 
disconnections. Web 2.0 technology now allows mass self-communication or networks that join many-to-many in the sending and receiving of messages that bypass the mass media and generally escape government control. The logic embedded in such networks supports a major change in sociability as networked individuals build identities, contacts and outlooks from the resources on offer according to their needs and moods. Since the scope of network society is both global and local ('glocal'), such individuals are no longer tied to particular times and places. ICT enables the coordinates of our everyday lives to be transcended so that we can enter virtual times and places (computer games) and simultaneously perceive, think and act in both local and global terms (we buy fair traded goods locally to support banana growers whom we have learnt about on the internet). Networked individuals may simply escape into the social networks and virtual worlds that ICT offers, or they may become 'netizens' seeking more comprehensive and effective forms of global governance. Clearly, developments in the theory and practice of education for sustainable development (ESD) and TEfS are needed to acknowledge the rise of network society, the nature of students as networked individuals and the changing form of cultural power.

\section{Power in network society}

Castells (2011a) argues that power in network society is exercised through the construction of meaning and the hold of communications and media networks over the minds of people. Changes in social communication and sociability enabled by ICT allow a greater diversity of messages and meanings to reach wider audiences, but the communication and construction of meaning is still shaped by four different kinds of power:

- Networking power: the power of actors and organisations who control networks to include/exclude individuals and groups (the power of editors at BBC News to decide who is interviewed about an issue relating to sustainable development);

- Network power: the power that results from the standards or rules, or inclusion built into the network that guide and co-ordinate social interaction (the stated and hidden rules that need to be followed to work in or with the World Trade Organisation);

- Networked power: the power of actors over other actors in the network (the power of a moderator to edit or censor a contribution to a web-based discussion such as the Great Northern Debate);

- Network-making power: the power to programme specific networks according to the interests and values of the programmers and the power to link/delink different networks following alliances/falling out between the dominant actors of those networks (the power to decide what links appear on ESD websites).

While all these forms of power shape people's understanding of the world, Castells (2011a) considers network-making power to be the ultimate form of power. Recent events surrounding News International and its links with politicians and the police in the UK (the phone- 
hacking scandal) or the revelations concerning the privileged access given to the International Institute of Finance (a lobby group for 450 of the biggest banks in the world) to EU talks on Greece's future, illustrate the close links between networks of financial, corporate and political power and the media networks that represent their interests. Meanwhile, the web as a source of individual empowerment is under threat from corporations seeking to corral users into marketable segments (the 'walled gardens' created by Facebook and Apple) and from state power seeking control and censorship (China's great firewall). Laws are needed to protect our privacy and rights to speak and assemble in cyberspace, and Iceland's Modern Media Initiative provides a model of what is possible. Morozov (2011) and Mason (2012) adopt pessimistic and optimistic views on whether the internet will spread democracy around the world, and it is to the role of new technologies in enabling democratisation that we now turn.

\section{New technologies, green socialism and sustainable development}

It is now several decades since the writings of Ivan Illich and Andre Gorz warned us of the dangers of 'technofacism' in modern societies and argued the case for appropriate technology that liberates rather than enslaves citizens. Gorz (1980) saw ecology not as an end in itself but as an essential part of the larger struggle against capitalism that is able to adapt to ecological constraints. The main goal should be an economic, social and cultural revolution that abolishes capitalism and establishes new sustainable relationships between the individual and society, between people and nature. For Gorz (1980), the key to such a society lay in the potential of ICT to free people from work (through automation) so that they have time to manage their own affairs and develop civil society to such an extent that the state's role is simply that of spreading knowledge, equipping citizens for self-management and coordinating self-managing local communities from above. In 1980, he (Gorz, 1980) sketched a future France, with a 20 hour working week, a lively odd-job sector, a basic citizens' income paid at a flat rate to all irrespective of their employment status or income, environmentally sound forms of production and consumption and a cultural life that encouraged the development of rich, all-round personalities.

Gorz's ideas were taken up and developed by post-industrial and green socialists (Pepper, 1993; Little, 1998; Foster, Clark, \& York, 2010) who realised that the key to sustainability is the social control of capital to direct it into socially useful production and the social control of technology to ensure it is used in socially responsible ways. While these writers and others envisioned future utopias, green socialism has lacked a theory of transition or ways in which its utopias might be realised. Wright (2010) fills this gap by suggesting that socialists should adopt a 'flexible strategic pluralism' in the ways they approach the transition. This should be guided by a greater realism regarding economic systems; the multiple pathways they offer for increasing social power; the advantages and disadvantages of three logics of transformation.

Wright (2010) begins from the premise that socialism (democratic power over the allocation and use of productive resources) requires the radical democratisation of all arenas of power (the state, economy, civil society) with power rooted in civil society (social power) 
controlling both state and economic power. Since all economic systems (national economies, firms, etc.) are complex configurations of capitalist, statist and socialist elements, transformation should not be envisioned as a binary shift from one form of power to another, but a shift in the configuration of power relations that constitute economic hybrids. There are multiple institutional forms through which social power can be increased, and Wright (2010) identifies a pluralist model of socialism that offers seven different kinds of pathway for democratising power (statist socialism; social democratic economic regulation; associational democracy; social capitalism; social economy; cooperative market economy; participatory socialism). These pathways allow different specific real utopian innovations with regard to democratising the state (Wright, (2010) explores, for instance, municipal participatory budgeting, egalitarian public financing of electoral campaigns, random selection of citizens' assemblies) and economy (Wikipedia, the Quebec social economy for childcare and eldercare; unconditional basic income, solidarity funds, share-levy wage-earner funds, the Mondragon co-op and participatory economics). There are multiple strategic logics through which such innovative institutions can be constructed and advanced: ruptural (creating new institutions of empowerment through a sharp break with existing institutions and social structures); interstitial (building new forms of social empowerment in the niches and margins of capitalist society); symbiotic (extending and deepening the institutional forms of popular social empowerment while at the same time helping solve certain problems faced by dominant classes and elites). Occupy Athens is an example of ruptural logic; the barter system in Volos, using local currency, is an example of interstitial logic, while the green left's advocacy of a green new deal for Europe might be considered an example of symbiotic logic.

Like Harvey's (2010) theory of co-revolutionary change, Wright's (2010) theory of transformation requires that we abandon Marx's strong theory of the inevitable demise of capitalism. Both require us to recognise multiple pathways, agents and logics, to accept strategic indeterminacy and to continually test and retest the limits of possibility as we act and learn our way to sustainability. Wright (2010) provides a summary of the likely changes, most, if not all of them, enabled by new technologies:

Unconditional basic income frees up time for social economy participation. Share-levy wage-earner funds and solidarity funds enhance the capacity of unions and other associations to control firms and investments. Worker-owned cooperatives are revitalized by new information technologies which make cooperation among cooperatives easier, and new cooperative market infrastructures are developed which buffer producer cooperatives from destructive market pressures. Direct state involvement in the economy is combined with new forms of associational participation which improve the efficiency and accountability of state enterprises. Participatory budgeting diffuses across a wide range of cities and extends to new domains of government spending. And entirely new institutions as yet unforeseen are invented to push forward social empowerment in new ways (Wright, 2010, p. 373).

If social empowerment is the key to green socialism and sustainability, then it is vital that the web remains a source of empowerment so that groups within civil society are able to use so- 
cial media to debate and promote radical social alternatives. Such tools enable online activism (Hill, 2010) and deliberative democracy (Baber \& Bartlett, 2005; Chadwick, 2009; Williamson, 2011) that can balance the interests of nature and future generations alongside current human interests and allows citizens to develop the kind of outlook that underpins ecological, cosmopolitan and global citizenship (Huckle, 2008). Such democracy is based on a set of core propositions: political equality of participants; interpersonal reasoning as the guiding political procedure; the public giving, weighing, acceptance or rejection of reasons. These also underpin the critical social theory of Habermas (Horster, 1992) that explains why deliberative democracy is needed to prevent science and technology serving minority interests and how the views of citizens might be moved towards a reasoned consensus on their application based on sound argument and reliable evidence. Since science and technology can only know nature in instrumental terms, they should be constantly weighed against other knowledge when applied to sustainable development. Such knowledge includes critical political ecology that is alert to the social construction of all knowledge, supposedly neutral explanations of ecological reality and multiple discourses of sustainable development. Citizens can arrive at ecologically rational decisions provided they consider a wide range of knowledge and values covering what is technically possible, culturally appropriate, morally and politically just. This assumption underpins critical pedagogy (eco-pedagogy) in ESD (Huckle, 1996; Kahn, 2008) and TEfS should introduce such pedagogy and demonstrate how it can be enriched by such ideas as those of Castells (2008, 2011abc), Wright (2010), Gorz (1980), Harvey (2011) and others.

\section{Network society, global civil society and green socialism}

In network society, the public sphere or space for debate on public affairs shifts from the local to the global and is increasingly constructed around global communication networks. This space is occupied by a global civil society that has arisen due to the decreased ability of nationally based political systems to manage the world's problems. It structures and channels citizen debates over such issues as sustainable development towards the networked state and consists of a variety of social interests including transnational business; world religions; public intellectuals; individuals and organisations promoting diverse models and discourses of sustainable development and global democracy. Castells (2008) recognises four different kinds of organisation within global civil society which overlap in their efforts as they engage with the pathways and logics that Wright (2010) outlines, innovate with institutions and shape debate and policy on sustainable development.

- Local civil society actors defending local interests. For instance, labour unions defending local jobs against outsourcing or local fishermen protesting against foreign-owned factory ships.

- Non-governmental organisations with a global frame of reference. For instance, Greenpeace, Oxfam or the Business Council for Sustainable Development.

- Social movements that aim to control the process of globalisation. For instance, 
the Zapatistas defending Mexicans against NAFTA, the anti-globalisation movement.

- Movements seeking to shift public opinion that use the media system and horizontal, autonomous networks of communication. For instance, UK Uncut protest against tax avoidance, Occupy Wall Street, Adbusters.

Castells (2011bc) addressed Occupy London and analysed it in a subsequent lecture in Cambridge. He regards its use of ICT and media to win wide support and introduce alternative ideas to a wider public as being critical elements in its success. While the mainstream media depicted it as marginal, unlawful and over, it experimented with participatory planning and deliberative democracy and was inspired by utopias including those associated with green socialism. Determined to make the case that bankers should pay for the crisis they had caused and that politicians no longer represented citizens, the worldwide Occupy movement demonstrated that social change begins in people's minds and develops as they build networks and challenge network-making power (Gessen et al., 2012).

\section{Sustainability, critical and digital literacies}

Having outlined how TEfS might explore the role of ICT in enabling an unsustainable neoliberal capitalism and its potential role in the transition to a more sustainable green socialism, I now intend to link ESD and TEfS to critical and digital literacies. Luke and Woods (2009) review approaches to critical literacy that might be introduced within TEfS and suggest that it involves engagement with the major texts, discourses and modes of information in a culture. Critical literacy attempts to attend to the ideological and hegemonic function of texts, and critical pedagogy is one means by which these are revealed. While critical literacy and pedagogy are underpinned by a variety of philosophical assumptions and pedagogical emphases that Luke and Woods survey (including those based on Habermas' critical theories), they share a commitment to the use of literacy for purposes of equity, social justice and sustainability. "They aim for nothing less than readers, writers, listeners and viewers who have a cogent, articulated and relevant understanding of texts, their techniques, their investments and their consequences, and who are able to use these understandings and capacities to act mindfully and justly to change their worlds" (Luke \& Woods, 2009, p. 9).

Lankshear and Knobel (2008) review the different meanings of digital literacy that have accumulated over recent years and distinguish between technical or instrumental forms that list specific skills and technique (computer literacy) and critical forms that emphasise mastery of ideas and insist on careful evaluation of information and intelligent analysis and synthesis (media literacy). Critical approaches focus on the cognitive and socio-emotional aspects of working in digital environments where information is multimediated and the networked individual has to be skilled at deciphering complex images and sounds as well as the syntactical subtleties of words. They encompass the ability to understand and use information in multiple forms from a variety of sources when it is presented via digital codification: blogs, video 
games, text messages, online social network pages, discussion forums, internet memes, FAQs, online search results and so on.

Unfortunately, a 'digital divide' is opening up between home and school.

...we are witnessing a widening gap between the culture of the school and the culture of children's lives outside school. In their leisure time, children are encouraged to see themselves as active participants, navigating their way independently through complex multimedia environments. Yet in school they are expected to submit to a pedagogic regime that is fundamentally premised on the testing of decontextualized skills and knowledge. By and large the use of information and communication technology in school signally fails to engage with the ways in which young people are now relating to information, and with the ways they choose to communicate (Buckingham, 2007, p. 178).

Digital technologies suggest a radical new way of learning (Siemens, 2004)) and the need to change curriculum and pedagogy (Collins \& Halverson, 2009; Jouneau-Sion \& Sanchez, 2011). Pass and Creech (2008), Tella and Adu (2009) and Blewitt (2006) have reviewed the opportunities and challenges that ICT provides for ESD more generally, while Cifuentes, Merchant and Vural (2011) have examined the role of Web 2.0 technologies in the related field of global citizenship education. It is my intention to maintain a focus on critical literacy and pedagogy, and, following Lambert and Morgan's (2010) argument regarding ICT and geography teaching, what is needed is not merely a 'tech-savvy' approach that capitalises on the interactivity of Web 2.0 to enliven ESD (YouTube rather than PowerPoint presentations, blogs rather than essays, teachers and students contributing to wikis), but an approach that sees all knowledge relating to sustainable development as being socially constructed and provides students with opportunities to reflect and to act the kind of ideas outlined in the earlier sections of this paper as mediated by digital technology. Such learning would develop sustainability literacy (their ability to read the symptoms and causes of unsustainable development and write more sustainable futures) whilst also contributing to political literacy and the development of identity. Clearly, this has wide implications for TEfS requiring course of initial and continuing professional development to apply relevant theory to the development of critical pedagogy that seeks both digital and sustainability literacy.

In such merging of critical sustainability and digital literacies, TEfS should follow Buckingham $(2009,2012)$ by approaching media not as technologies but as cultural forms that represent the world and communicate ideas. It should acknowledge that bias is unavoidable, that information relating to sustainable development is inevitably shaped by discourse and ideology and that in network society media texts play a key role in the politics of sustainable development and are shaped by and in turn shape the kind of network power that Castells (2008, 2011abc) outlines. Buckingham (2008) suggests how four key concepts central to media education (representation, language, production and audience) can be applied to the analysis of websites and the key questions he uses are equally relevant to other texts communicated via social media. He (Buckingham, 2008) argues that media production should accompany media analysis as a means of developing media/digital literacy, and this may involve blogging, social networking, game making, small-scale video production. The aim is for 
teachers and students to understand how the media work, how meaning is created, who has the power and how that power can be challenged.

Mocigemba (2008) presents three theses and anti-theses relating to podcasting and sustainable development that can be applied to social media more generally (Table 1). TEfS and ESD linked to digital literacy should encourage teachers and students to evaluate these as they encounter and produce a variety of texts. Table 1 also provides a starting point for us to consider whether the above ideas already outlined can be put into practice.

Table 1. Web 2.0 (social media) and sustainable development (SD): Based on Mocigemba (2008)

Web 2.0 media can open up debate on SD by:

- Turning lecture into debate

- Lowering entry barriers to discourse

- Turning passive governance into a deliberative process

- Increasing civic engagement and political participation particularly amongst the young

- $\quad$ Tailoring messages to specific audiences who can receive them free of space/time/ cost constraints

- $\quad$ Expressing minority views and placing new issues on the agenda

- $\quad$ Encouraging active searching, selecting and responding (learning)

Web 2.0 media can enforce a culture and lifestyle of SD by:

- Overcoming the immunisation, ignorance and rejection prompted by threatening, moralising and patronising environmental communication

- $\quad$ Emphasising solutions, inducing positive emotions and mentioning additional immaterial benefits

- $\quad$ Associating SD with popular media brands like YouTube ('The medium is the message')

- Using user generated content to increase identification with sustainability values and overcome suspicion of manipulation/ propaganda

- $\quad$ Providing unifying narratives for groups sympathetic to SD, labelled cultural creatives or post materialists

\footnotetext{
Web 2.0 is a useful tool for the existing SD community because:

- It is a way to create synergy and use network power to attract public attention

- It can reduce dependence on established media and journalists by bypassing, critiquing and correcting them (citizen journalists)

- Its use raises the reputation of the SD community
}

Opening the debate on SD via Web 2.0 media

is only a theoretical possibility because:

- Audiences may be small or non-existent (but any audience worthwhile)

- Communication may not stimulate genuine dialogue (need for online leadership/ moderators)

- Online participation in debates on SD topics appeals mainly to those already familiar with the blogosphere

- Talk does not necessarily lead to action

- Attention slips from the public to the private sphere as with mobile phones

- $\quad$ People enjoy their passivity and retreat into privacy

Web 2.0 media will have little effect outside cyberspace because:

- Audience is low and messages have little social and cultural impact (no mass self communication a reality)

- Cultural creatives may be further divided by digital creatives and their diverse messages

- They will reinforce the digital divide, many have no access or lack media literacy
Web 2.0 is dangerous for the established SD community because:

- Citizen journalists may understand SD less well than traditional journalists

- Consideration of SD becomes dependent on media literacy and an affinity with ICT

- Copyright hinders translation of traditional media materials dealing with SD

- Its use threatens the reputation of the SD community 


\section{From theory to practice, YouTube in the ESD classroom}

After outlining the role of social media in providing a new space for civic engagement and linking this to Habermas' notion of communicative rationality, Kellner and Gooyang (Gooyang, 2009; Kellner \& Gooyang, 2009) consider the potential and limitations of YouTube to empower young citizens. While YouTube is embedded in capitalist social relations (owned by Google) and can be considered another play-pen in the capitalist fun house or a medium dominated by self-expression, narcissism, silliness and entertainment, mainly used by relatively rich, white male English speakers, Kellner and Gooyang (2009) suggest that, linked to a critical media pedagogy, it offers some potential as a reservoir of true enlightenment. YouTube allows individuals to 'organise and deploy novel strategies of self-education and social transformation'; can be seen as a 'dialogical learning community'; and, by allowing users to post videos and opinions, it provides opportunities for them to exhibit personal autonomy and active and critical citizenship. In this way, it extends and democratises civil society.

The hopes and fears raised by Mocigemba (2008) and Kellner and Gooyang (2009) can be tested as part of TEfS, by examining the potential of YouTube to stimulate learning and communication around the central ideas outlined in this article. Do YouTube videos address alternative development paths for Europe, including more sustainable paths linked to socialism and the radical democratisation of European society? Do they address Wright's ideas on the multiple pathways and logics shaping the prospects for change and Castells' (2008, 2011abc) ideas about network society? Are they likely to appeal to students in classrooms, to provide an extended forum for debate and discussion and a rich medium for critical media pedagogy?

To begin to answer these questions, I searched for relevant videos on YouTube, selected nine that are listed in Table 2 and noted related statistics on how many times they had been viewed and how many comments and expressions of like/dislike they had attracted.

Table 2. Nine YouTube videos relevant to debate on sustainable development in Europe (viewed and statistics recorded on 25/04/12)

\begin{tabular}{cccccc}
\hline Title & Date uploaded & Uploaded by & Viewed by & Comments & $\begin{array}{c}\text { Likes/ } \\
\text { dis- } \\
\text { likes }\end{array}$ \\
\hline $\begin{array}{c}\text { European Green } \\
\text { Party spokesperson } \\
\text { Phillippe Lamberts } \\
\text { MEP on the Spanish } \\
\text { protests }\end{array}$ & $30 / 05 / 2011$ & $\begin{array}{c}\text { European Green } \\
\text { Party }\end{array}$ & 58 & 0 & $2 / 0$ \\
\hline $\begin{array}{c}\text { Susan George - } \\
\text { Green New Deal }\end{array}$ & $06 / 09 / 2011$ & attactv & 2673 & 1 & $18 / 1$ \\
\hline $\begin{array}{c}\text { Participatory } \\
\text { budgeting comes to } \\
\text { Kensington }\end{array}$ & $24 / 10 / 2011$ & Dorablount & 308 & 0 & $0 / 0$ \\
\hline $\begin{array}{c}\text { The story of We the } \\
\text { Citizens (Citizens } \\
\text { Assembly, Ireland) }\end{array}$ & $09 / 12 / 2011$ & thecitizenVideo & 79 & 0 & $1 / 0$ \\
\hline
\end{tabular}


Sequel to Table 2.

\begin{tabular}{cccccc}
\hline $\begin{array}{c}\text { Greek town develops } \\
\text { bartering system } \\
\text { without Euros }\end{array}$ & $04 / 04 / 2012$ & LeakSource2012 & 15248 & 28 & $162 / 0$ \\
\hline $\begin{array}{c}\text { Coops can work - } \\
\text { Mondragon Coop 1 }\end{array}$ & $01 / 11 / 2011$ & FreeTheWorker & 278 & 0 & $1 / 0$ \\
\hline Occupy Athens & $06 / 10 / 2011$ & Redandblack540 & 691 & 3 & $7 / 1$ \\
\hline $\begin{array}{c}\text { Manuel Castells at } \\
\text { Occupy London }\end{array}$ & $26 / 11 / 2011$ & VoicingTheCity & 958 & 0 & $4 / 0$ \\
\hline $\begin{array}{c}\text { The Icelandic } \\
\text { Modern Media } \\
\text { Initiative }\end{array}$ & $20 / 05 / 11$ & corbettreport & 2326 & 6 & $62 / 1$ \\
\hline
\end{tabular}

With reference to Mocigemba's three theses/anti-theses, we can note that, while there is relevant content on YouTube, it is not attracting large audiences and there is a lack of related comment and debate. The video statistics facility shows the location and gender of an audience that is generally located in Europe and male. Developing any sort of unified narrative on sustainable development from the vast array of videos on offer requires prior knowledge of sustainability politics and skilled use of search terms. The ratio of likes to dislikes suggests that the videos are viewed by those already sympathetic to the arguments presented and by following links to organisations that uploaded the videos, the viewer may gain access to networks that aid their ongoing search for political and personal identity.

Turning to Wright's and Castells' ideas, there is clearly a need for teachers to approach YouTube with these in mind as they provide relevant search terms and criteria for evaluating videos for classroom use. There is sufficient content on YouTube to illustrate their ideas but also evidence that this is as yet not a key medium for learning about and debating radical social change. Once selected by the teacher or the students, YouTube videos can aid the development of political literacy and sustainability citizenship, but this will require a fair amount of conventional teaching and learning if the videos are to be interpreted in ways associated with critical media literacy.

Searching YouTube suggests that few schools are uploading videos on sustainability topics and that those that are uploaded mainly focus on sustainable schooling. Teachers' concerns about e-safety may explain this lack of engagement, as may the relatively high level of sustainability literacy needed to comprehend much of the material uploaded to YouTube. The medium has potential, but as yet its significance for ESD in the lives of school students pales into insignificance compared with its use for entertainment and distraction from real world issues.

\section{And the present challenge?}

As I write in late April 2012, it is clear that Europe's networked state is not working. An austerity programme, which diminishes sovereignty, consigns youth to high levels of unemployment and steers Europe towards a decade of stagnation, is destroying the social solidarity on which the European Union depends. Some citizens continue to demand the radical democratisation of Europe that would sweep away the existing neoliberal treaties of the EU, establish a 
new framework for economic integration and political union, redistribute wealth and employ ecological planning to recover from capitalist crisis. This paper has argued that their arguments should feature in TEfS and ESD along with those that are more reformist and conservative. The critical understanding and use of social media should become a key element of TEfS, but teacher educators will need to be realistic about what such media currently offer.

\section{Acknowledgement:}

This work has been developed within the framework of the ICTeESD project that has been funded from the European Commission (ERASMUS Multilateral Programme Virtual Campus Project No. 510212-LLP-1-2010-1-GR-ERASMUS-EVC (2010-3494). The content of the paper reflects the views of the authors, and the Commission cannot be held responsible for any use which may be made of the information contained therein.

\section{References:}

Baber, W. F., \& Bartlett, R. V. (2005). Deliberative environmental politics: Democracy and ecological rationality. London: MIT Press.

Blewitt, J. (2006). The ecology of learning: sustainability, lifelong learning and everyday life. London: Earthscan.

Buckingham, D. (2007). Beyond technology: Children's learning in the age of digital culture. Cambridge: Polity Press.

Buckingham, D. (2008). Defining digital literacy - what do young people need to know about digital media. In A. Lankshear \& M. Knobel (Eds.), Digital literacies: Concepts, policies and practices (pp. 73-91). Oxford: Peter Lang.

Buckingham, D. (2009). Beyond technology: Rethinking learning in an age of digital culture. In J. Pettersen (Ed.), Youth, media, democracy: Perceptions of new literacies (pp. 37-43). Dublin: Centre for Social and Educational Research.

Buckingham, D. (2012). The future of media literacy in the digital age: Some challenges for policy and practice. Retrieved April 28, 2012, from http://medienimpulse.at/articles/view/143

Castells, M. (2008). The new public sphere: Global civil society, communication networks, and global governance. ANNALS, AAPSS [The Annals of the American Academy of Political and Social Science], 616, 78-93. DOI: 10.1177/0002716207311877.

Castells, M. (2011a). A network theory of power. International Journal of Communication, 5, 773-787.

Castells, M. (2011b). Manuel Castells on alternative local economies. Retrieved April 28, 2012, from http://www.youtube.com/watch?v=1hpd3GPuDBc

Castells, M. (2011c). Humanitas, Manuel Castells at the University of Cambridge, Lecture 3, YouTube. Retrieved April 28, 2012, from http://www.youtube.com/watch?v=hNlycKjnxTk 
Chadwick, A. (2009). Web 2.0: New challenges for the study of e-democracy in the era of informational exuberance. I/S: A Journal of Law and Policy for the Information Society, 5(1), 9-41.

Cifuentes, L., Merchant, Z., \& Vural, O. (2011). Web 2.0 technologies forge the way for global citizenship. Mustafa Kemal University Journal of Social Sciences Institute, 8(15), 295-312.

Collins, A., \& Halverson, R. (2009). Rethinking education in the age of technology: The digital revolution and the schools. New York: Teachers College Press.

De Santos, R., Husson, M., Katz, C., Mandel E. and others. (2009). Socialists and the capitalist recession. London: Resistance Books.

Ferry, J. (2011). Understanding the European Union in a cosmopolitan sense. What is civic participation? Paper presented at the European workshop on closing the empowerment gap through citizenship education, 17-19 November 2011, Warsaw, Poland, Networking European Citizenship Education.

Foster, J. B., Clark, B., \& York, R. (2010). The ecological rift, capitalism's war on the earth. New York: Monthly Review Press.

Gessen, K., Greif, M., Leonard, S., Taylor, A., Resnick, S., Schmitt, E., et al. (2012). Occupy! Scenes from Occupied America. London: Verso.

Gooyang, K. (2009). The future of YouTube: Critical reflections on YouTube users' discussion over its future. Retrieved April 28, 2012, from http://escholarship.org/uc/item/9tn362r2

Gorz, A. (1980). Ecology as politics. Boston: South End Press.

Harvey, D. (2010). The enigma of capital and the crises of capitalism. London: Profile Books.

Harvey, D. (2011). David Harvey at Occupy London, YouTube. Retrieved April 28, 2012, from http://www.youtube.com/watch?v=ht8W30gkVac

Held, D. (1995). Democracy and the global order: From the modern state to cosmopolitan governance. Cambridge: Polity Press.

Hill, S. (2010). Models of online activism and their implications for democracy and climate change. Retrieved April 28, 2012, from http://www.fdsd.org/wordpress/wp-content/ uploads/Online-activism-democracy-and-climate-change.pdf

Horster, D. (1992). Habermas: An introduction. Philadelphia: Pennbridge.

Huckle, J. (1996). Teacher education. In J. Huckle \& S. Sterling (Eds.), Education for sustainability (pp. 105-119). London: Earthscan.

Huckle, J. (2008). Sustainable development. In J. Arthur, I. Davies \& C. Hahn (Eds.), The Sage handbook of education for citizenship and democracy (pp. 342-354). London: Sage.

Jouneau-Sion, C., \& Sanchez, E. (2011). Web 2.0 is challenging school. Retrieved April 28, 2012, from http://hal.archives-ouvertes.fr/docs/00/61/82/85/PDF/iigwe2011_Jouneau_ sanchez.pdf

Kahn, R. (2008). From education for sustainable development to ecopedagogy: Sustaining 
capitalism or sustaining life? Green Theory \& Praxis, 4(1), 1-14. DOI: 10.3903/gtp.2008.1.2.

Kellner, D., \& Gooyang, K. (2009). YouTube, critical pedagogy, and media activism: An articulation. Retrieved April 28, 2012, from http://pages.gseis.ucla.edu/faculty/kellner/ essays/2009_Kellner-Kim_UT_Politics\%20and\%20PedagogyFINAL\%20April\%2009.pdf

Lambert, D., \& Morgan, J. (2010). Teaching geography 11-18: A conceptual approach. Maidenhead: Open University Press.

Lankshear, A., \& Knobel, M. (2008). Introduction. In A. Lankshear \& M. Knobel (Eds.), Digital literacies - concepts, policies, practices (pp. 1-16). Oxford: Peter Lang.

Little, A. (1998). Post-industrial socialism: Towards a new politics of welfare. London: Routledge.

Luke, A., \& Woods, A. F. (2009). Critical literacies in schools: A Primer. Voices from the Middle, 17(2), 9-18.

Mason, P. (2012). Why it's kicking off everywhere: The new global revolutions. London: Verso.

Mocigemba, D. (2008). P4P, podcasting for participation: How can digital grassroots media support sustainable development? Retrieved April 28, 2012, from http://195.37.26.249/ijsc/ docs/artikel/02/02_mocigemba.pdf

Morozov, E. (2011). The net delusion. New York: Public Affairs.

O'Connor, J. (1991). Socialism and ecology. Capitalism, nature, socialism, 2(3), 1-12. DOI: $10.1080 / 10455752.2012 .701856$.

Paas, L., \& Creech, H. (2008). How ICTs can support education for sustainable development: Current uses and trends. Paper prepared with the support of the Province of Manitoba and presented to Manitoba Education, Citizenship and Youth. Winnipeg, Manitoba, Canada.

Pepper, D. (1993). Eco-socialism, from deep ecology to social justice. London: Routledge.

Shutt, H. (2010). Beyond the profits system: Possibilities for a post-capitalist era. London: Zed Books.

Siemens, G. (2004). Connectivism: A learning theory for the digital age. Retrieved April 28, 2012, from http://www.ingedewaard.net/papers/connectivism/2005_siemens_ ALearningTheoryForTheDigitalAge.pdf

Tapscott, D., \& Williams, A. D. (2008). Wikinomics: How mass collaboration changes lives. London: Atlantic Books.

Tapscott, D., \& Williams, A. D. (2010). MacroWikinomics: Rebooting business and the world. London: Atlantic Books.

Tella, A., \& Adu, E. O. (2009). Information and communication technology (ICT) and curriculum development: The challenges for education for sustainable development. Indian Journal of Science and Technology, 2(3), 55-59.

Williamson, A. (2011). Driving civic participation through social media. Paper presented the European workshop on perspectives of Web 2.0 for citizenship education in Europe, Brno, Czech Republic, 7-9 April 2011, Brno, Czech Republic, Networking European Citizenship 
Education.

Wright, E. O. (2010). Envisioning real utopias. London: Verso.

\section{Correspondence:}

John Huckle is an ESD consultant who formerly taught at the University of York, De Montfort and South Bank universities. Email: john@huckle.org.uk. He can be contacted via his website at: http://john.huckle.org.uk 